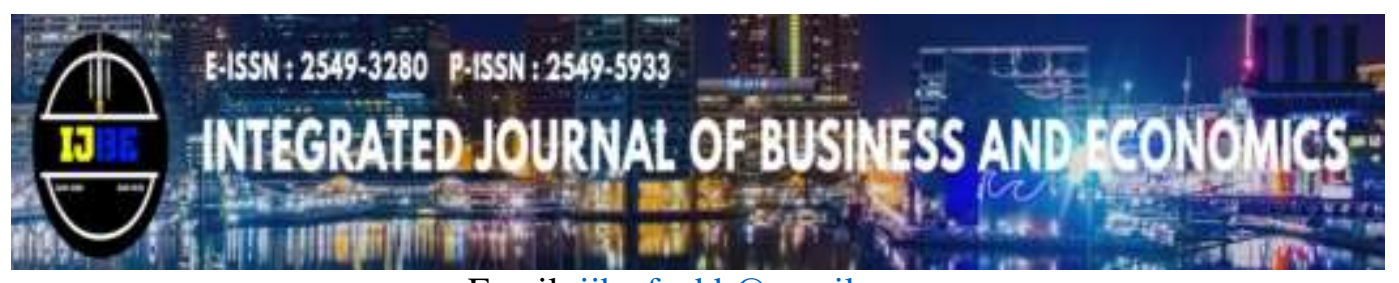

Email: ijbe.feubb@gmail.com

Laman: http://ojs.ijbe-research.com/index.php/IJBE/index

\title{
Patchouli Farmers Strategy For Business Development In Meranti Tengah Village, Toba Samosir Regency
}

\author{
Nicholas Marpaung ${ }^{a}$, Feby Aulia Safrin ${ }^{b}$ \\ ${ }^{a, b}$ Universitas Sumatera Utara, Indonesia \\ nicholasgandi@gmail.com
}

\begin{abstract}
This research aims to determine the strategy of business development of patchouli oil farmers in improving economic welfare, to analyzing obstacles or barriers in running the cultivation and production of patchouli oil in Central Meranti. Type of research is descriptive with a qualitative approach because the research intends to understand what phenomena experienced by the subject of research. The research method uses Purposive technique or deliberate with consideration of Central Meranti is one of the villages that the majority of its citizens still hang the livelihood as a patchouli oil farmer. Data collection methods are obtained from primary data and secondary data where primary data is obtained through interviews with Informant as well as direct observations of the field, and secondary data is obtained from the relevant agencies. The Data obtained is then analyzed using SWOT analysis. The results showed that there only 2 families that still maintain patchouli oil farming efforts with patterns and strategies to develop this business in a simple way. In addition, the limited information such as the writing and socialization of patchouli is still limited from the government to the farmers so that more farmers are switching commodities.
\end{abstract}

\section{Article Info}

- Received : April 28, 2020

- Revised : June 8, 2020

- Published : June 10, 2020

- No. Pages : 147 - 159

- DOI : 10.33019/ijbe.v4i2.268

- JEL : E32

- Keywords : strategy, business, development, patchouli farmers 


\section{Introduction}

Indonesia is known as the largest producer of essential oils in the world, especially Patchouli Oil. Indonesia is also a supplier of $90 \%$ of the world's patchouli oil needs. Essential oils are produced from various types of plants and one of them is Patchouli (Pogostemon Cablin Benth) through the process of patchouli leaf and stem distillation. Essential oils (patchouli oil) function as a binder element (fictitious) the best aroma for fragrances (perfume) so that the resulting fragrance can last a long time and is not easily lost due to the washing or evaporation process. This makes patchouli essential oil the most perfect mixture for making perfumes and has not been replaced by synthetic substances that exist today so that the demand and needs of patchouli oil domestically and abroad remain high and large.

Indonesia's volatile oil exports from year to year also experienced fluctuations in which in 2014 were at 4,036 tons, in 2015 at 3,990 tons, in 2016 around 5,190 tons and in 2017 increased sharply to 30,770 tons (http://validnews.com). In Indonesia, there are several regions that contribute to the supply of patchouli oil for export needs or domestic needs. The Province of Nanggroe Aceh Darussalam contributed to $60 \%$ of the national patchouli oil supply and then by Provinces of North Sumatra, West Sumatra and Central Java. According to the Ministry of Agriculture, in the last 2 years, that is 2018 to 2019, the increase in patchouli oil exports has remained intact even though it is not clear the overall amount.

The area which is the center of patchouli oil production in North Sumatra Province is in the regency of Dairi and Toba Samosir. In Toba Samosir Regency there is a Meranti Tengah village in the Pintupohan Meranti District. This village is a village in Toba Samosir where the people still depend on their livelihoods as patchouli oil farmers. The limitations of standardized distillation facilities and the lack of government assistance both in the form of education and finance for the cultivation and distillation of patchouli oil are a challenge for the residents of Meranti in cultivating patchouli plants. In addition, the increasingly massive land use change and price uncertainty caused by the patchouli oil price play by middlemen (middlemen) makes this business increasingly abandoned by the people of Meranti Tengah.

Patchouli oils are one of Indonesia's traditional export commodities that have been cultivated since before World War II. Indonesia is the number one producer of essential oils with the largest 40 known Patchouli oils. It is estimated that there are 12 types of Indonesian essential oils which are exported to the international market from 80 Patchouli oils in the world.

Seeing the great potential of Patchouli oil derivative products at the global level, it seems very ironic if Indonesia can only be a spectator. Therefore, to be able to increase the added value of the essential oil business, Indonesia must continue to innovate. 
The government needs to implement policies including assistance to farmers, application of the latest technology that can support the production of high-quality essential oils and a shared vision to achieve product quality in accordance with market demand. Everything is possible if there is a strong will from all parties involved. It is very ironic if patchouli is considered a very valuable commodity on the world market but farmers do not get government assistance which is actually complacent with the status of the world's largest patchouli oil exporter. This research will discuss in depth the problems faced by Patchouli farmers in the Meranti Tengah village and how farmers' strategies in developing businesses and how farmers can maintain their businesses.

\section{Literature Review}

\section{Concepts of Business Development Strategies}

Basically strategy is a tool to achieve goals. Goldworthy and Ashley (1996: 98) propose seven basic rules in formulating a strategy are

a) It must explain and interpret the future, not only the present,

b) The strategic direction must be able to determine the plan and not vice versa,

c) The strategy must focus on competitive advantage, not solely on financial considerations,

d) It must be applied from the top down, not from the bottom up,

e) Strategy must have an external orientation,

f) Flexibility is essential

g) Strategy must be centered on long-term results

\section{Review of Business Development Library}

Business development is the responsibility of every entrepreneur or entrepreneur who needs foresight, motivation and creativity (Anoraga, 2007: 66). Business development is the task and process of analytical preparation of potential growth opportunities, support and monitoring of the implementation of business growth opportunities, but does not include strategic decisions and implementation of business growth opportunities. As for large businesses, especially in the field of industrial technology, the term business development refers to managing and managing strategic relationships and alliances with others. To carry out business development, it needs support from various aspects such as production and processing, marketing, human resources, technology and others.

The elements of business development there are 2 elements (Anoraga, 2007), namely:

1. Internal elements are categorized as someone who has the intention of an entrepreneur / entrepreneur to develop his business to become bigger, know ways of how to develop products or develop a business that is run and make a consistent budget to find out the expenditure and income of products for the continuity of his business .

2. External elements are categorized as someone who is always updated with information from outside the business that is currently being run, recognizes environmental conditions that are conducive to business, obtaining funds not 
only by borrowing from outside parties, the range of products that always supports creativity and innovation.

\section{Stages of Business Development}

According to Anoraga (2007: 90), the stages of business development include: Phase I: Identification of Opportunities, identifying opportunities supported by data and information. Information can usually be obtained from various sources such as: 1) Company plans, 2) Small management suggestions and suggestions, 3) Programs and government, 4) Results of various business opportunity research 5) Kadin or similar business associations. Phase II: Formulate business alternatives. After information gathered and analyzed then the company leadership or business manager can formulated any business that might be opened. Phase III: Alternative Selection, Many alternatives must be chosen one or several of the best and prospective alternatives. For prospective businesses, the basis for their selection can include the following criteria: 1) Market Availability, 2) Failure Risk, 3) Price. Phase IV: Implementing Selected Alternatives, After determining alternatives, the next stage of implementing selected businesses. Phase V: Evaluation, Evaluation is intended to provide corrections and improvements to the business being run. In addition to Supriatna and Aminah (2014) in their paper agreed that the company's financial condition, human resources, consumer attitudes, information technology and location are internal and external factors that influence in developing business.

\section{Business Development Techniques \\ Increased Economic Scale}

This method can be done by increasing the scale of production, labor, technology, distribution systems, and place of business (Suryana, 2006: 156). This is done if business expansion or increased output will reduce long-term costs, which means achieving economies of scale. Conversely, if an increase in output results in an increase in long-term costs, then it is not good to do. In other words, if the products and services produced have reached the most efficient point, then expanding the scale of the economy cannot be done, because it will drive up costs.

\section{Expansion of Business Coverage}

This method can be done by adding new types of businesses, new products and services that are different from those currently produced (diversification), as well as with different technologies. Thus, the scope of economic business can be defined as a diversification of economic business characterized by the total combined production costs (joint total production cost) in producing two or more types of products together is smaller than the sum of the production costs of each product if separately produced. Expansion of the scope of this business can be done if the entrepreneur has sufficient capital.

\section{SWOT Analysis}

SWOT analysis (Strength Weakness Opportunities Threats) is a tool commonly used to analyze the internal and external environment in order to achieve a systematic approach and support for a decision making situation. SWOT analysis can be done using one of two matrix models, namely the SWOT matrix or the 
TOWS matrix. The matrix model takes precedence over external factors (threats and opportunities), then looks at internal capabilities (strengths \& weaknesses). The TOWS matrix produces 4 strategies (Rangkuti, 2006), namely:

1. SO Strategy (Strategy of strength - opportunity), creating a strategy that uses strength to take advantage of opportunities.

2. Strategy WO (Strategy of weakness - opportunity), creating a strategy that minimizes weaknesses to take advantage of existing opportunities.

3. ST Strategy (Strength - threat strategy), creating a strategy by utilizing strengths to avoid or minimize the impact of external threats.

4. WT Strategy (Strategy of weakness - threat), based on activities that are defensive and try to minimize, and avoid threats.

Previous research on the topic of agricultural commodity business development strategies has been widely presented in a number of national and international journals, including research entitled Corn Biscuit Business Development Strategy in Sustainable Farmers Women's Groups Subun Tua'lele Village, West Insana District, North Central Timor Regency by Kolo and Hutapea (2016). The research used a SWOT strategy analysis tool and successfully identified the strengths, weaknesses, opportunities and threats for the development of the farmer's business so that farmers could find out the potential and obstacles faced. Another study entitled Analysis of business development strategies for soursop juice drinks by Kurniawan and Haryati (2017) also uses SWOT Analysis to identify business development strategies. The study found an obstacle often faced by farmers was the lack of innovation to diversify their products.

This study has a deeper concern and will try to escape from the stigma of agribusiness that arises because the object of this research is among farmers. This research offers a State of the art research that is focused on business development strategies in the realm of business administration and emphasizes the sustainability of products and processes.

\section{Research Methods}

The study was conducted for 1 year, by selecting research locations in Meranti Tengah Village Pintu Pohan Meranti District, Toba Samosir Regency. Desa Meranti Tengah as a village whose majority of residents work as patchouli farmers is the reason for choosing this location as a research location. The approach that will be used in this research is a qualitative approach. Qualitative research aims at obtaining a complete picture of a matter according to the human point of view studied. Poerwandari (2007) revealed that qualitative research produces and processes data that is descriptive in nature, such as interview transcripts, field notes, pictures, photographs, video recordings, etc. According to Sugiyono (2017) Using purposive sampling technique is the right choice in the situation of sample limitations, so this study uses purposive sampling with certain considerations namely the limitations of informants in the field.

The informants in this study were patchouli oil farmers, we conducted in-depth interviews with farmers even though the number of farmers in Meranti village was not much anymore. because the number of farmers is no longer large, we decided 
to interview all existing farmers. then we reduce the interview results and provide additional documentation as a complement to the results of the study.

\section{Results}

Desa Meranti Tengah is a village in the District of Pintupohan Meranti, Toba Samosir Regency, North Sumatra Province. The village is inhabited by 413 people, an area of $98.85 \mathrm{~km} 2$ with an average population density of 4.15 people / $\mathrm{km} 2$. The livelihoods of the majority of the population are farmers and planters.

Table 1. The Area of Villages in the District of Pintupohan Meranti

\begin{tabular}{|c|c|c|c|}
\hline & Desedikelurahan &  & $\begin{array}{c}\text { reasig torthedop twas } \\
\text { (You) }\end{array}$ \\
\hline \multicolumn{2}{|r|}{ (क) } & (2) & (ख) \\
\hline or. & Ambar Halim & 1408 & 0.37 \\
\hline $0 z$ & Pintu Pohan Dolok & 1362 & 4.91 \\
\hline 03. & Pintu Pohan & 1565 & 5,64 \\
\hline 0.4 : & Halado & 1474 & 5.32 \\
\hline os. & Maranti Timur & $6 \sec$ & 23.69 \\
\hline 06. & Maranti Tengah & 9 aes & 36.66 \\
\hline or & Meranti Utara & 5384 & 19.42 \\
\hline & Jumtak & 27127 & 700.00 \\
\hline
\end{tabular}

Source: tobasamosikab.bps.go.id

\section{Research Results}

Overview of Patchouli Farming

Business management patchouli farmland in Meranti Tengah Village so far have been carried out by several families traditionally. The majority of Central Meranti patchouli growers plant patchouli species of Aceh Patchouli or Pogostemon Cablin Benth. Based on interviews with interviewees, the reason why farmers in Central Meranti planting Patchouli Aceh is because a type of patchouli originating from the mainland of the Philippines and the Malay Peninsula has characteristics of not flowering, downy leaves with oil content of 2.5-5.0\%. This type of patchouli is widely cultivated in Indonesia, including in Meranti Tengah Village. As a type of patchouli that has a higher oil content than other types, patchouli aceh is the most widely planted patchouli type in Meranti Tengah village. Because the more oil content, the sales quantity will also be higher.

Patchouli Farmers in Meranti Tengah Village have a fairly simple principle in running patchouli oil farming. The principles of traditional oil management and marketing should be changed by good marketing management too, especially to keep getting stable prices. Lack of information in the marketing of patchouli oil is a major obstacle that should not depend on collectors' demands where farmers can utilize more effective marketing methods to get high selling points. 


\section{Increasing the Economical Scale of Patchouli Farmers}

Economic scale is a theory that describes the phenomenon of decreasing production costs per unit in a company coupled with an increase in production volume (output). If the business unit gets bigger, the production costs will be smaller. How could output increase but the cost of production per unit actually decreases? In layman's logic, any increase in output is generally followed by an increase in unit production costs. The assumption is that factors of production such as raw materials (inputs) and labor also increase, so it should also affect production costs per unit which increases or is higher. This assumption may be correct, but not always right. This actually happened to Patchouli Farmers in Meranti Tengah Village, where production or yields could be increased because of the cost of production (planting) that could be reduced. the increase in economies of scale in Central Meranti Village patchouli farmers should be achieved easily. Costs for purchasing seeds included in production costs (planting) can be reduced because raw materials can be obtained without cost.

Although for other farmers, there are still those who still pay for getting seeds of better quality compared to those already available in nature. Mass production or planting of patchouli seeds in bulk and without cost in Meranti Village can actually reduce the cost of production per unit because there are no raw material costs. Simply put, the purchase of raw materials (seeds) in large quantities should get discounts so that the price of raw materials (inputs) becomes cheaper. However, with the condition of the seeds (raw materials) that are available free of charge with the same frequency / working hours for processing land and the same number of workers, processing these raw materials or planting the seeds will lead to lower production costs.

Thus, the economies of scale at Meranti patchouli farmers are being seen through their success in efficiency. The efficiency of these farmers is generally influenced by the size or scale or size of the land they own. Farmers who have large land area tend to be more efficient compared to farmers who have small scale land. Patchouli Farmers in Central Meranti Village have actually done cost efficiency by ignoring the quality of raw materials (seedlings) that are no less important as a determinant of income increases. There are still many farmers who prioritize raw materials from nature or the results of their own cultivation so that the quality is inadequate which results in the production of patchouli leaves that are less than optimal and not too have a good quality.

\section{Expansion of Patchouli Farmers' Business Coverage}

The expansion of patchouli farmer's business scope is certainly different from the expansion of business coverage in companies or organizations. As an independently and traditionally managed business, the expansion of the scope of patchouli farming in Meranti Tengah Village has actually been implemented simply and self-taught. If the company or organization is expanding its business scope to include several indicators such as expanding the scale of production, labor, technology, business location and distribution system as well as the business network, then the expansion of patchouli farmer business coverage in Central Meranti starts from expanding the land to be planted in patchouli, 
diversifying patchouli commodity to be planted, and efforts to adopt the use of a new machine for the distillation process even though it has not been realized until now.

\section{Expansion of patchouli plant land}

Based on field observations, the number of patchouli farmers in the village of Meranti Tengah, found the fact that only 15 people left or families who work as patchouli farmers, with details 3 out of 15 farmers are not active farmers but only seasonal farmers who plant patchouli when the price is predicted to rise . The vast land owned by certain farmers is one of the main reasons why patchouli farmers in Meranti village are not developing in terms of quantity. Patchouli Farmers in the village of Meranti Tengah actually have implemented an expansion of business scope with most of them choosing to rent land to be planted patchouli for farmers who do not have land. Likewise for farmers who have large enough land, they will also look for new land to plant patchouli as well as a strategy to increase their income.

\section{Patchouli Production/Crop Diversivication}

The majority of patchouli farmers in Desa Meranti Tengah do not have specific actions or strategies in diversifying or making derivative products from their main production product, patchouli, despite attempts to fill patchouli spaces with other patchouli with other economically valuable crops such as beans, chilies, tomatoes and even planting with other types of patchouli is a diversification and maximization of resources in a fairly simple way. The size of the farmer's efforts and whether or not to provide a significant increase in income can be categorized as a diversification effort in the smallest scope of agriculture.

\section{Technology and Machinery}

Technology and machinery are important elements in expanding the scope of business. In businesses engaged in agriculture, the use of technology and machinery is absolutely necessary. Technology in agriculture can be used to predict climate and weather, while machinery can be used to streamline labor and time management before and after harvest. However, in patchouli farming in Meranti Tengah Village, the use of technology and machinery is still failing to be carried out due to the lack of technological understanding and inability to use machines or the price of machines that are too expensive.



Figure 1. Patchouli Distillation Tool of Central Meranti Patchouli Farmers 


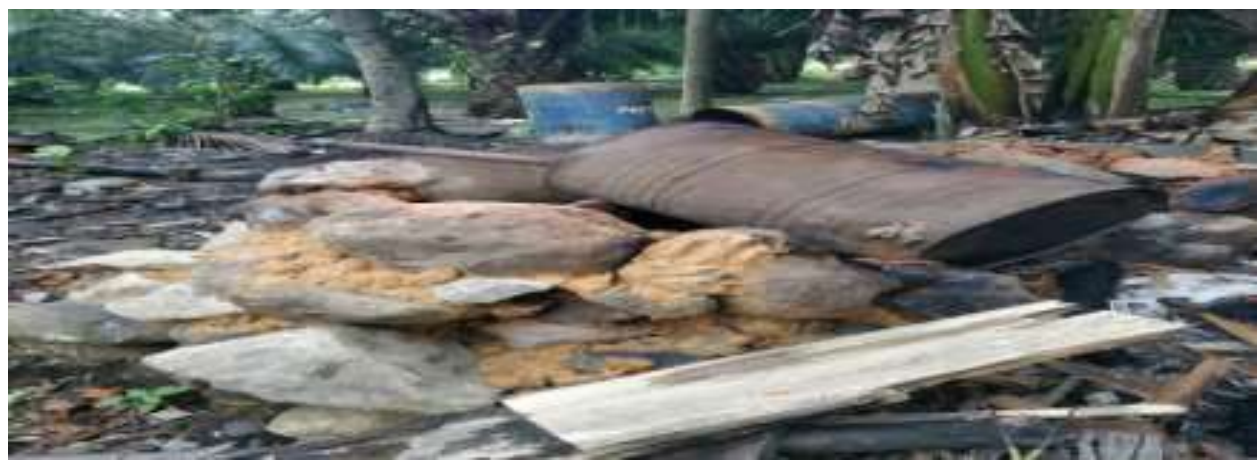

Figure 2. Patchouli Oil Receptacle Drum Containers

Utilization of technology and machinery by patchouli farmers in Meranti Tengah Village based on the observations of researchers is still not well utilized. The use of technology for weather and climate forecasting in the context of the planting process, identifying rainfall and others is also not well considered. Likewise with the use of a processing machine for dried patchouli leaves, namely distillation that is still done very simply without using the right machine. The distillation process uses only simple tools that are independently modified by farmers and are used together. Supposedly, the use of more sophisticated machines will make it easier for farmers to get maximum yields. By using machines such as Figure 1 and Figure 2, we can be sure that the yield from distillation of dried leaves will not get maximum results. The latest and sophisticated machine should be able to improve the distillation results because by using traditional machines like that is possible for the oil still contained in patchouli leaves will not come out perfectly. Therefore, the government's attention to patchouli farmers in the village of Meranti Tengah in terms of information assistance and the provision of distillery equipment is absolutely needed by farmers because based on the results of interviews, none of the patchouli farmers have ever gotten that.

\section{Identification of SWOT Analysis of Internal and External Factors Internal Factors}

Based the observations and results of the analysis of the patchouli farmer respondents at the research location in Meranti Tengah Village, the factors that can be identified as strengths and weaknesses of the respondents are as follows:

Table 2. Internal Factors

\begin{tabular}{|c|c|}
\hline Strength & Weaknesses \\
\hline 1. Aceh Patchouli Quality & 1. Simple farming equipment \\
\hline 2. Increased Patchouli & 2. Lack of guidance to farmers \\
\hline 3. Patchouli & Limitad altination lond \\
\hline experience & 5. Limited capital \\
\hline $\begin{array}{l}\text { 4. Potential of natural } \\
\text { resources owned }\end{array}$ & \\
\hline $\begin{array}{l}\text { 5. Availability of Abundant } \\
\text { Seeds }\end{array}$ & \\
\hline
\end{tabular}




\section{External Factors}

External factors that become opportunities and threats in patchouli farming at the study site are as follows:

Table 3. External Factors

\begin{tabular}{|l|l|}
\hline \multicolumn{1}{|c|}{ Opportunity } & \multicolumn{1}{c|}{ Threat } \\
\hline $\begin{array}{l}\text { 1. Increased demand for } \\
\text { patchouli oil }\end{array}$ & 1. Pests and diseases \\
2. Transportation access & 3. The high cost of farming \\
$\begin{array}{l}\text { 3. Close marketing } \\
\text { channels }\end{array}$ & $\begin{array}{l}\text { 4. Lack of institutions supporting the development } \\
\text { of Patchouli Oil Farming }\end{array}$ \\
$\begin{array}{l}\text { 4. Market opportunities } \\
\text { 5. Availability of vacant } \\
\text { land }\end{array}$ & 5. Determination prices by collectors \\
\hline
\end{tabular}

SWOT Analysis as a strategy for developing Patchouli Agriculture business IFAS Matrix Analysis (Internal Factor Analysis System)

Based on the internal factors above illustrating the strengths and weaknesses to determine the condition of Patchouli Oil which is summarized in the IFAS (Internal Factor Analysis System) matrix, more details can be seen in the following table

Table 4. Internal Matrix System Factor Analysis Strategy (IFAS)

\begin{tabular}{|c|c|c|c|c|}
\hline \multirow{2}{*}{ No } & \multirow{2}{*}{ ANALYSIS SWOT FACTOR } & \multicolumn{3}{|c|}{ Score $=$ Value $x$ Rating } \\
\hline & & Value & Rating & Score \\
\hline \multicolumn{5}{|c|}{ Strongth (S): } \\
\hline 1 & Aceh Patchouli Quality & 0.12 & 4.00 & 0.48 \\
\hline 2 & Increased Patchouli production & 0.10 & 3.94 & 0.41 \\
\hline 3 & Patchouli farming experience & 0.10 & 3.47 & 0.34 \\
\hline 4 & Potential of natural resources owned & 0.10 & 3.53 & 0.36 \\
\hline 5 & Availability of Abundant Seeds & 0.10 & 2.47 & 0.26 \\
\hline \multicolumn{2}{|r|}{ Total } & 0.53 & & 1.85 \\
\hline \multicolumn{5}{|c|}{ Weaknesses (W): } \\
\hline 1 & Simple farming equipment & 0.09 & 2.65 & 0.25 \\
\hline 2 & Lack of guidance to farmers & 0.09 & 2.41 & 0.23 \\
\hline 3 & Lack of market information & 0.09 & 2.18 & 0.20 \\
\hline 4 & Limited cultivation land & 0.08 & 2.00 & 0.17 \\
\hline \multirow[t]{3}{*}{5} & Limited capital & 0.10 & 2.41 & 0.25 \\
\hline & Total & 0.47 & & 1.09 \\
\hline & Total Internal Factor & 1.00 & & 2.94 \\
\hline
\end{tabular}

Source: Data processed, 2020

Based on the results of calculations made in table above, the total value of IFAS obtained for patchouli farming is 2.94 consisting of a strength score of 1.85 or (64.92\%) with the highest strength score of 0.48 , namely the quality of Aceh Patchouli and the score weakness of 1.09 or $(35.08 \%)$ with the lowest weakness factor score of 0.17 , namely limited cultivation land. Therefore, by paying attention to existing strengths and weaknesses, Nilam farming still occupies a strategic position that is strong enough to continue to be developed because the strength factor is more dominant than the weakness factor. 
Table 5. External Factor Analysis System (EFAS)

\begin{tabular}{|c|c|c|c|c|}
\hline \multirow{2}{*}{ No } & \multirow{2}{*}{ ANALYSIS SWOT FACTOR } & \multicolumn{3}{|c|}{ Score $=$ Value $x$ Rating } \\
\hline & & Value & Rating & Score \\
\hline \multicolumn{5}{|c|}{ Opportunity $(0)$ : } \\
\hline $\mathbf{1}$ & Increased demand for patchouli oil & 0.11 & 3.82 & 0.42 \\
\hline 2 & Transportation access & 0.11 & 2.65 & 0.28 \\
\hline 3 & Close marketing channels & 0.11 & 2.65 & 0.28 \\
\hline 4 & Market opportunities & 0.12 & 3.88 & 0.45 \\
\hline 5 & Availability of vacant land & 0.10 & 3.35 & 0.32 \\
\hline \multirow{2}{*}{\multicolumn{5}{|c|}{$\begin{array}{r}\text { Total } \\
\text { Threat }(\mathbf{W}):\end{array}$}} \\
\hline & & & & \\
\hline 1. & Pests and diseases & 0.10 & 3.18 & 0.32 \\
\hline 2. & The existence of competition & 0.10 & 3.29 & 0.33 \\
\hline 3. & The high cost of farming & 0.09 & 2.65 & 0.24 \\
\hline 4. & $\begin{array}{l}\text { Lack of institutions supporting the } \\
\text { pment of Patchouli Oil Farming }\end{array}$ & 0.09 & 3.06 & 0.28 \\
\hline 5. & Determination prices by collectors & 0.08 & 1.53 & 0.12 \\
\hline & Total & 0.46 & & 1.29 \\
\hline & Total Factor Internal & 1.00 & & 3.04 \\
\hline
\end{tabular}

Source: Data processed, 2020

Based on the results of calculations made in the above table, the total value of EFAS for patchouli oil farming is 3.04 consisting of an opportunity score of 1.75 or $(59.23 \%)$ with the highest chance score of 0.45 , namely market opportunity and threat score 1.29 or $(40.77 \%)$ with the lowest threat factor score of 0.12 , namely the price game by collectors. Noting the opportunities and threats, patchouli oil farming is still in a strategic position to continue to be developed because opportunity scores are more dominant than threat scores.

\section{Alternative decision making strategies in SWOT analysis}

Based on the assessment of IFAS (Internal Factor Analysis System) and EFAS (External Factor Analysis System) conducted on the patchouli farmer business development strategy in Meranti Tengah Village, an average IFAS score of 2.94 with a strength score of 1.85 or $(62.84 \%)$ and the weakness value is 1.09 or $(37.15 \%)$ while the total EFAS average is 3.04 from the opportunity value of 1.75 or $(57.57 \%)$ and the threat value is $1.25(42.43 \%)$. To find out the business development based on the assessment of internal and external factors, a reduction is made between the number of strengths and weaknesses in the X-axis, and the reduction between the number of opportunities and threats for the (Y) axis, then the value, $\mathrm{X}=(\mathrm{SW})=1.85-1.09=0.76$ and the value of $\mathrm{Y}=(\mathrm{OT})=1.75-1.29=$ 0.47 .

Thus obtained figures on both axes $(\mathrm{X}$ and $\mathrm{Y}=0.76$ and 0.47 which are positive for the development of patchouli oil farmers in Meranti Tengah village, for more details can be seen in Figure 3. 


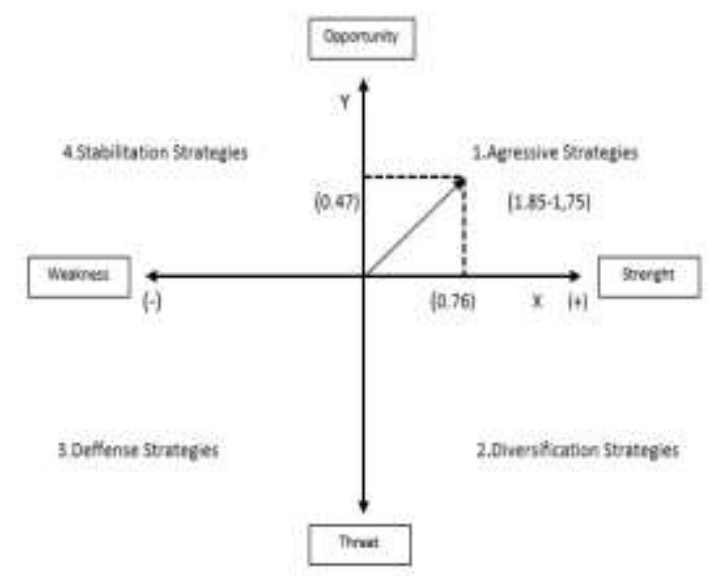

Figure 3. Alternative decision making strategies in SWOT analysis

The results of data analysis in the SWOT diagram obtained coordinates $0.47 ; 0.76$ which coordinates are in quadrant 1 , which is an aggressive strategy. This strategy is a very favorable situation. Patchouli business development has strengths and opportunities that are united and mutually supportive, that is by using the all power factor to take advantage of existing opportunities. It can be concluded that the results of the SWOT analysis of the development strategy of Patchouli Oil Farming in Meranti Tengah Village obtained IFAS value of 2.94 and EFAS value of 3.04 and the right strategy in the patchouli farmer business development strategy is an aggressive strategy.

\section{Conclusion and Suggestion}

There are five external strategic factors that become opportunities and threats for patchouli farmers. The factors that become the dominant opportunity for patchouli farmers are increasing demand for patchouli oil, transportation access, close marketing channels, market opportunities, availability of vacant land. Whereas the dominant threats are pests and diseases, competition, high farm costs, lack of patchouli support institutions, and game prices by collectors.

The strategy that can be used by Patchouli Oil Farming in Meranti Tengah Village obtained from the SWOT analysis is an aggressive strategy, a strategy that allows this business to continue to develop its business, increase growth, expand and achieve maximum progress. The facts found are related to patchouli planting patterns which are carried out without clear measurements, inadequate use of technology and machinery so that farmers' yields have not been able to be consistently improved. Besides that, the role of the government was apparently not so significant and real in distributing assistance in the form of socialization, education or capital assistance for patchouli farmers in Meranti Village. This is an irony considering that Patchouli is a very valuable export commodity and Indonesia's status as a State supplying 90 percent of the world's essential oils, but the government has not really focused on the supervision and guidance of patchouli farmers in remote areas such as in Meranti Tengah Village. 


\section{ACKNOWLEDGEMENT}

This research is a Young Lecturer scheme research funded by the University of North Sumatra through the USU TALENTA program in the 2019 Budget year.

\section{References}

1) Anoraga, Pandji ( 2007). Pengantar Bisnis: Pengelolaan Bisnis dalam Era Globalisasi. Jakarta.

2) Goldworthy \& Ashley (1998). Australian Public Affairs Information Service. Australia: APAIS.

3) Kolo \& Hutapea (2016). Strategi Pengembangan Usaha Biskuit Jagung di Kelompok Wanita Tani Lestari Desa Subun Tua'lele, Kecamatan Insana Barat, Kabupaten Timor Tengah Utara. Jurnal Agribisnis Lahan Kering-2016 International Standard of Serial Number 2502-1710

4) Kurniawan, Haryati (2017). Analisis Strategi Pengembangan Usaha Minuman Sari Buah Sirsak. Jurnal Teknologi dan Manajemen Agroindustri Vol 6 No 2. 97-102. 2017

5) Poerwandari, K. (2007). Pendekatan Kualitatif. Jakarta. Universitas Indonesia

6) Rangkuti, Freddy (2010). Strategi Promosi Yang Kreatif dan Analisis Kasus Integrated Marketing Communication, Gramedia Pustaka Utama, Jakarta.

7) Sugiyono. (2017). Metode Penelitian Kuantitatif, Kualitatif, dan R\&D. Bandung : Alfabeta, CV.

8) Supriatna, S dan Aminah, M. (2014). Analisis Strategi Pengembangan Usaha Kopi Luwak (Studi Kasus UMKM Careuh Coffee Rancabali- Ciwidey, Bandung. Jurnal Manajemen dan Organisasi.Vol V, No 2 (2014). h. 227-243.

9) Suryana, (2006). Kewirausahaan Pedoman Praktis: Kiat dan Proses Menuju Sukses, Edisi Ketiga, Penerbit Salemba, Jakarta.

10) Ulber, Silalahi (2009). Metode Penelitian Sosial. Bandung: PT. Refika Aditama. 